\title{
Geologic Characterization of Young Alluvial Basin-Fill Deposits from Drill-Hole Data in Yucca Flat, Nye County, Nevada
}

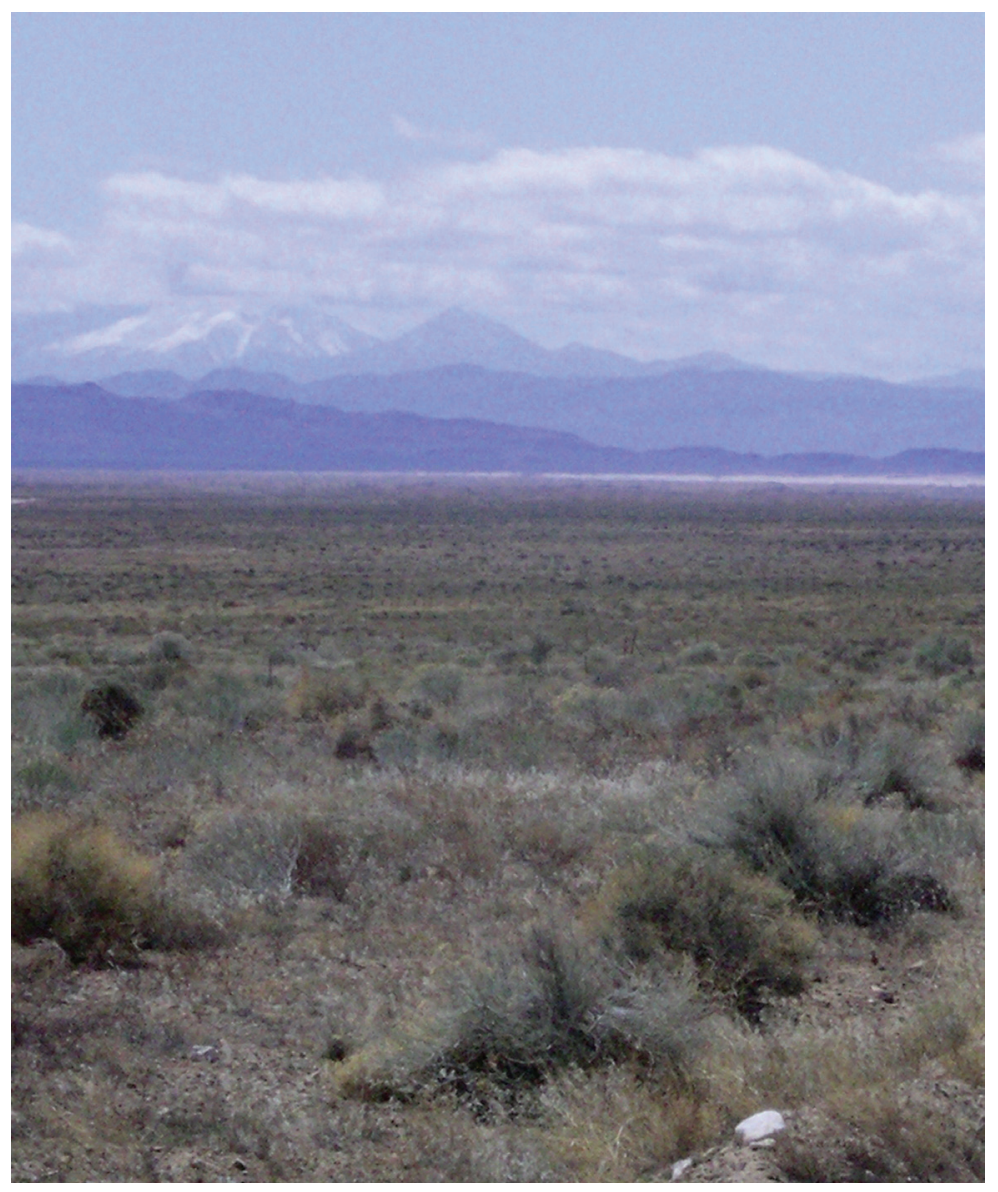

This report was produced in cooperation with the Department of Energy through Interagency Agreement DE-Al52-01NV13944.

Scientific Investigations Report 2007-5062 


\section{Geologic Characterization of Young Alluvial Basin-Fill Deposits from Drill-Hole Data in Yucca Flat, Nye County, Nevada}

By Donald S. Sweetkind and Ronald M. Drake II

Scientific Investigations Report 2007-5062

This report was produced in cooperation with the Department of Energy through Interagency Agreement DE-Al52-01NV13944. 


\section{U.S. Department of the Interior DIRK KEMPTHORNE, Secretary}

\section{U.S. Geological Survey \\ Mark D. Myers, Director}

\section{U.S. Geological Survey, Reston, Virginia: 2007}

For product and ordering information:

World Wide Web: http://www.usgs.gov/pubprod

Telephone: 1-888-ASK-USGS

For more information on the USGS--the Federal source for science about the Earth, its natural and living resources, natural hazards, and the environment:

World Wide Web: http://www.usgs.gov

Telephone: 1-888-ASK-USGS

Any use of trade, product, or firm names is for descriptive purposes only and does not imply endorsement by the U.S. Government.

Although this report is in the public domain, permission must be secured from the individual copyright owners to reproduce any copyrighted materials contained within this report.

Suggested citation:

Sweetkind, D.S., and Drake, R.M. II, 2007, Geologic characterization of young alluvial basin-fill deposits from drill-hole data in Yucca Flat, Nye County, Nevada: U.S. Geological Survey Scientific Investigations Report 2007-5062, $17 \mathrm{p}$.

This report supersedes the following Open-File Report: Sweetkind, Donald, and Drake II, Ronald M., 2007, Geologic characterization of young alluvial basin-fill deposits from drill hole data in Yucca Flat, Nye County, Nevada: U.S. Geological Survey Open-File Report 2006-1390. 


\section{Contents}

Abstract
Introduction
Purpose and Scope
Description of the Study Area
$\quad$ Geologic Setting
Interpretation of Drill-Hole Data
3D Lithologic Modeling
Summary
Acknowledgments

\section{Figures}

1. Index map of Yucca Flat and the Nevada Test Site, Nevada..............................................

2. Geologic map of Yucca Flat showing drill-hole locations, cross-section lines and boundary of 3D lithology model...................................................................................

3. West-east cross sections showing interpreted drill-hole lithologic data..........................7

4. North-south cross section showing interpreted drill-hole lithologic data........................8

5. Three-dimensional portrayals of drill-hole lithologic data. .............................................10

6. Perspective view of vertical sections cut through 3D lithology model of Yucca Flat. ....11

7. Perspective views of $3 \mathrm{D}$ lithologic model showing distribution of lithologic classes....13

8. Perspective view of multiple vertical sections cut through $3 \mathrm{D}$ lithology mode

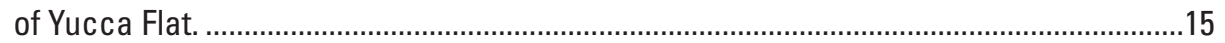

\section{Table}

1. Generalized lithologic classes based on drill-hole descriptions .......................................5 


\section{Conversion Factors}

\section{Inch/Pound to SI}

\begin{tabular}{lcll}
\hline & Multiply & \multicolumn{1}{c}{ By } & To obtain \\
\hline & \multicolumn{2}{c}{ Length } & \\
\hline foot $(\mathrm{ft})$ & 0.3048 & meter $(\mathrm{m})$ & \\
inch & 25.4 & millimeter & \\
inch & 2.54 & centimeter & \\
mile & 1.609 & kilometer & \\
\hline
\end{tabular}

Vertical coordinate information is referenced to the National Geodetic Vertical Datum of 1929 (NGVD 29).

Horizontal coordinate information is referenced to the Nevada State Plane Coordinate System, central zone, North American Datum of 1927 (NAD27), in feet.

Elevation, as used in this report, refers to distance of a point on the Earth's surface above the vertical datum. 


\title{
Geologic Characterization of Young Alluvial Basin-Fill Deposits from Drill-Hole Data in Yucca Flat, Nye County, Nevada
}

\author{
By Donald S. Sweetkind and Ronald M. Drake II
}

\begin{abstract}
Yucca Flat is a topographic and structural basin in the northeastern part of the Nevada Test Site in Nye County, Nevada, that has been the site of numerous underground nuclear tests; many of these tests occurred within the young alluvial basin-fill deposits. The migration of radionuclides to the Paleozoic carbonate aquifer involves passage through this thick, heterogeneous section of Tertiary and Quaternary rock. An understanding of the lateral and vertical changes in the material properties of young alluvial basin-fill deposits will aid in the further development of the hydrogeologic framework and the delineation of hydrostratigraphic units and hydraulic properties required for simulating ground-water flow in the Yucca Flat area. This report by the U.S. Geological Survey, in cooperation with the U.S. Department of Energy, presents data and interpretation regarding the three-dimensional variability of the shallow alluvial aquifers in areas of testing at Yucca Flat, data that are potentially useful in the understanding of the subsurface flow system. This report includes a summary and interpretation of alluvial basin-fill stratigraphy in the Yucca Flat area based on drill-hole data from 285 selected drill holes. Spatial variations in lithology and grain size of the Neogene basin-fill sediments can be established when data from numerous drill holes are considered together. Lithologic variations are related to different depositional environments within the basin such as alluvial fan, channel, basin axis, and playa deposits.
\end{abstract}

\section{Introduction}

Yucca Flat is a topographic and structural basin in the northeastern part of the Nevada Test Site (NTS) in Nye County, Nev. (fig. 1). Between the years 1951 and 1992, 659 underground nuclear tests took place in Yucca Flat; most were conducted in large vertical excavations that penetrated alluvium and the underlying Cenozoic volcanic rocks (U.S. Department of Energy, 2000).
Radioactive and other potential chemical contaminants at the NTS are the subject of a long-term program of investigation and remediation by the U.S. Department of Energy (DOE), National Nuclear Security Administration, Nevada Site Office, under its Environmental Restoration Program. As part of the program, the DOE seeks to assess the extent of contamination and to evaluate the potential risks to humans and the environment from byproducts of weapons testing. To accomplish this objective, the DOE Environmental Restoration Program is constructing and calibrating a ground-water flow model to predict hydrologic flow in Yucca Flat as part of an effort to quantify the subsurface hydrology of the Nevada Test Site. A necessary part of calibrating and evaluating a model of the flow system is to compile and analyze data related to heterogeneity of the component hydrogeologic units. This report by the U.S. Geological Survey (USGS), in cooperation with the DOE, presents data and interpretation regarding the threedimensional (3D) variability of the shallow alluvial aquifers in areas of testing at Yucca Flat, data that are potentially useful in the understanding of the subsurface flow system.

\section{Purpose and Scope}

The purpose of this study is to develop an understanding of lateral and vertical lithologic variability of Neogene sediments that make up the shallow basin fill of Yucca Flat. Understanding the configuration and character of the basin-fill sedimentary units is critical to delineating hydraulic properties and reducing uncertainty in three-dimensional simulations of ground-water flow in the Yucca Flat area. Recent stratigraphic studies of Cenozoic basins to the south of the NTS, including the Amargosa Desert Basin (Sweetkind and others, 2001; Taylor and Sweetkind, 2005) and the Pahrump Valley (Sweetkind and others, 2003) have shown that the three-dimensional stratigraphic variability of shallow alluvial sediments can be adequately characterized through interpretation of drill-hole lithologic data. We hoped that the use of similar techniques would yield similar results in the Yucca Flat basin. 


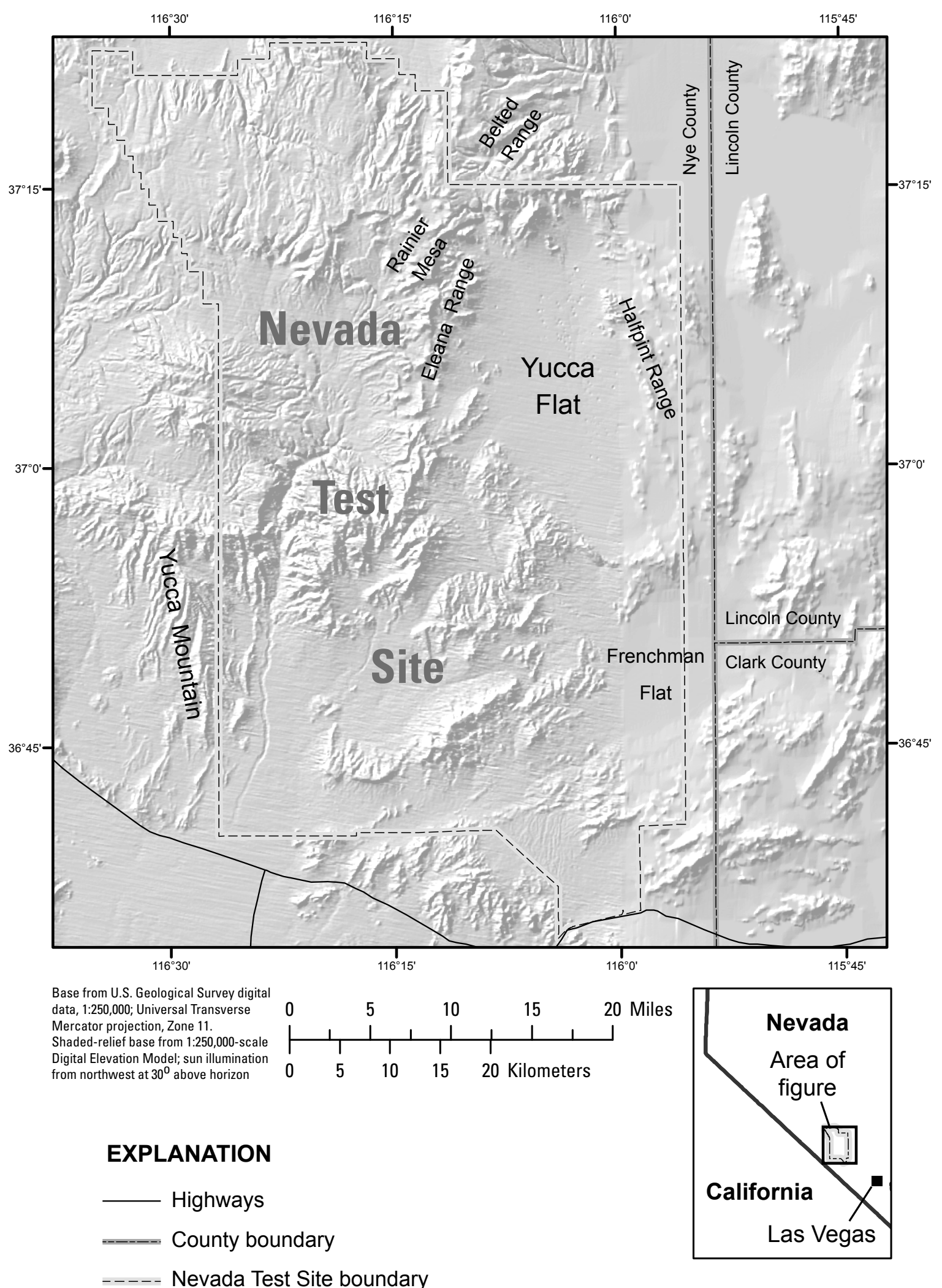

Figure 1. Index map of Yucca Flat and the Nevada Test Site, Nevada. 
This report presents a summary and interpretation of alluvial basin-fill stratigraphy in the Yucca Flat area based on lithologic data from 285 drill holes that were selected from more than 890 available drill holes in Yucca Flat. The drill holes that were used in this study were selected on the basis of location (the need to produce a suitable spatial distribution of data) and the presence of high-quality lithologic descriptions that could be interpreted in terms of depositional environment and facies information. Drill-hole lithologic data from the Neogene basin-fill sediments are evaluated in terms of lateral and vertical lithologic variations. These data are developed as geologic cross sections and 3D subsurface interpretations that show lateral and vertical changes in young alluvial basin-fill deposits, including spatial variations in lithology and grain size.

\section{Description of the Study Area}

\section{Physiographic Setting}

Yucca Flat is a topographically closed drainage basin that occupies much of the eastern part of the Nevada Test Site (fig. 1). The valley floor has no perennial surface water; Yucca Flat acts as a catchment for surface-water runoff and is a local depositional center for sediment. The low-relief topographic basin has a playa (seasonally dry lake) at the south end (fig. 2), and the basin is surrounded by low ranges of Tertiary volcanic rocks and underlying Paleozoic and Late Proterozoic sedimentary rocks (fig. 2) (Slate and others, 2000). In general, the valley floor slopes upward toward the surrounding ranges on a series of coalescing alluvial fans that ring the margins of the basin. Large, active alluvial channels extend into the basin from topographic highlands of Rainier Mesa, the Belted Range, the Eleana Range, and the Halfpint Range (figs. 1 and 2). These channels merge and ultimately drain to the playa at the south end of the basin.

\section{Geologic Setting}

The Cenozoic rocks in Yucca Flat consist of a thick alluvial section underlain by Miocene volcanic rocks and rare, thin, prevolcanic sedimentary rocks, all of which lie unconformably on variably deformed pre-Cenozoic rocks. The Miocene volcanic rocks that form the lower part of the basin fill were originally erupted from source areas in the southwestern Nevada volcanic field (Byers and others, 1976; Sawyer and others, 1994). The volcanic rocks include variably welded ash-flow tuff, ash-fall tuff, and reworked tuff; the thickness and extent of these rocks vary greatly within the basin. The lower part of the sequence of volcanic rocks, including pre-Belted Range Group rocks, the Belted Range and Crater Flat Groups, and the Wahmonie Formation (stratigraphic designations from Sawyer and others, 1994), consists of bedded and reworked, nonwelded, commonly zeolitized tuffs. The upper part of the sequence of volcanic rocks, including rocks from the Paintbrush and Timber Mountain Groups, consists mainly of welded ash-flow tuff.

The largely postvolcanic sedimentary basin fill that is the subject of this report consists of a mixture of loosely consolidated, coarse-grained, alluvial and colluvial deposits that were derived from the surrounding Cenozoic silicic volcanic and Paleozoic siliciclastic and carbonate sedimentary rocks, fine-grained basin axis and playa deposits, and localized eolian sand and rare basalt flows. Digital geologic map compilations of the Nevada Test Site at 1:120,000 scale (Slate and others, 2000) and 1:250,000 scale (Workman and others, 2002) have defined the map distribution and provided detailed descriptions for the surficial geologic units. As described by Workman and others (2002), coarse-grained surficial units consist of Holocene to Pliocene alluvium, colluvium, and minor eolian and debrisflow sediments associated with alluvial geomorphic surfaces (Swan and others, 2001; Potter and others, 2002). In general, fluvial deposits are predominantly sandy gravel, whereas alluvial fans typically show a gradational decrease in grain size from proximal to distal fan with distance from the mountain front (Workman and others, 2002). Local eolian accumulations consist of sand sheets or dune fields. Sediments generally are not cemented but tend to be more indurated with increasing depth. The fine-grained alluvial units consist of Holocene playa and (or) saltpan deposits that are commonly underlain by older playa or lacustrine sequences of middle to early Holocene and Pleistocene age (Workman and others, 2002). These rocks typically have coarse material and mixtures of moderately stratified to well-stratified silt, clay, and fine sand.

Structurally, the Yucca Flat basin is in general terms a simple half-graben dominated by north-striking, east-dipping, down-to-the-east normal faults of Cenozoic age such as the Yucca fault and the Carpetbag fault (Dockery, 1984; Carr, 1984) (fig. 2). Gravity models of the Yucca Flat basin define a Tertiary-Quaternary basin as much as $8,200 \mathrm{ft}$ deep to the east of the Carpetbag fault, a midbasin high to the west of the Carpetbag fault, and a shallower basin to the west of the high (Phelps and others, 1999; Ferguson and others, 1988). The Cenozoic volcanic units have been offset thousands of feet by the Carpetbag-Yucca fault system and related smaller faults (Phelps and McKee, 1999). The gravity data indicate that the Yucca Flat basin is deepest at its south end where it abuts the dividing ridge with Frenchman Flat to the south (Dockery, 1984), although few drill holes penetrate the entire thickness of the Tertiary section in this area. Yucca Flat is enclosed at its north end, where anticlinally folded Late Proterozoic rocks in the Halfpint Range converge with Paleozoic siliciclastic rocks near the south end of the Belted Range (Hinrichs, 1968). 

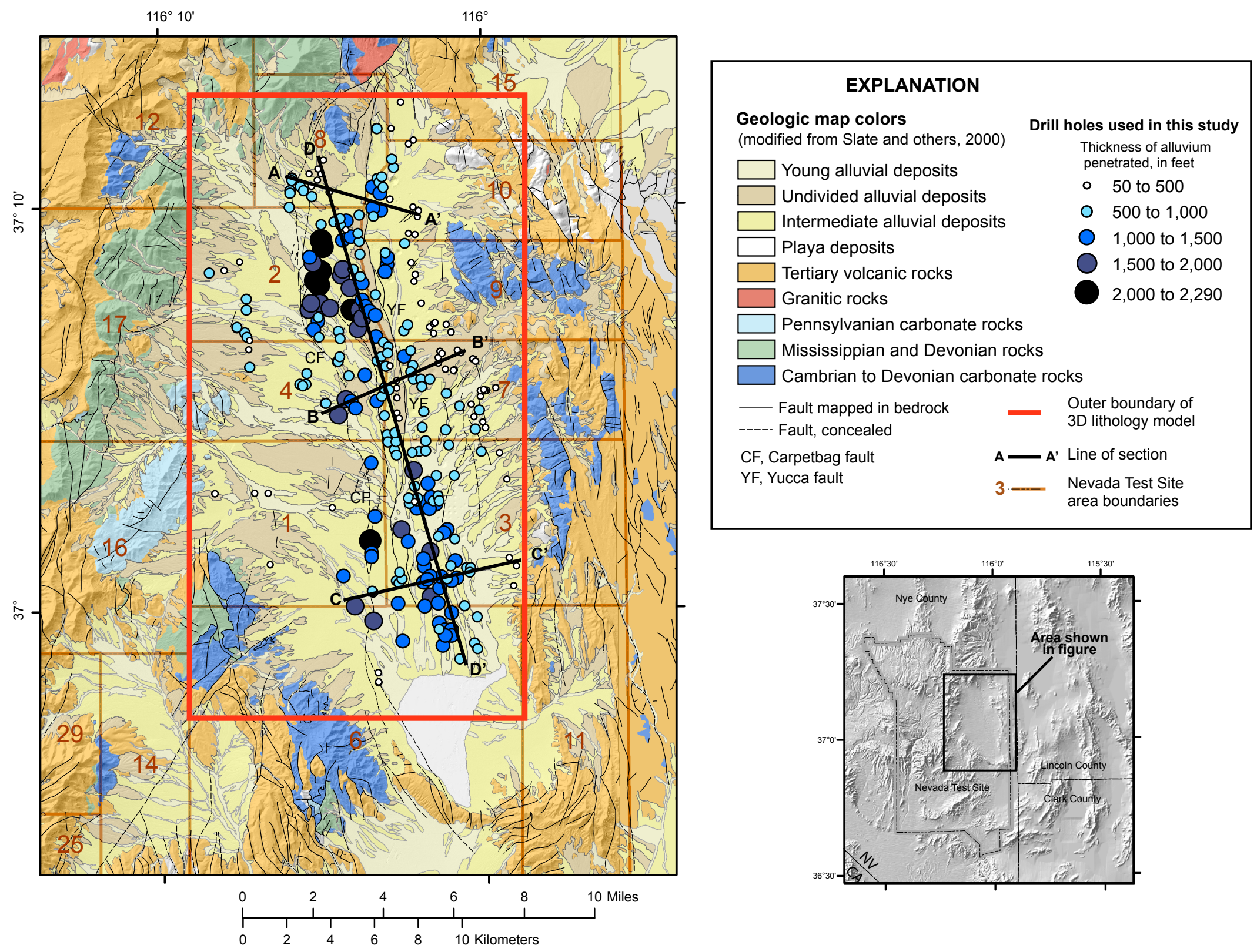

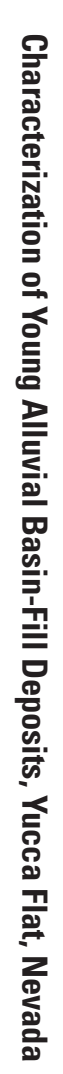

Figure 2. Geologic map of Yucca Flat showing drill-hole locations, cross-section lines, and boundary of 3D lithology model. 


\section{Interpretation of Drill-Hole Data}

Subsurface lithologic information was extracted from data tabulations from the numerous drill holes in Yucca Flat. For most of the holes, no cuttings are preserved for the alluvial fill, and the lithologic descriptions represent the primary data source. Covington and Berger (1997) produced an extensive compilation of lithologic descriptions from depth-specific sample intervals of core and cuttings samples collected from more than 890 drill holes located in Yucca Flat. These data, and additional data from more recently drilled holes, have been compiled in recent years in digital form by USGS scientists (David Wood, written commun., 2003) for incorporation in the Ground-Water Site Inventory (GWSI) subsystem of the USGS National Water Information System (NWIS). The digital compilation of the drill-hole data is available at http://nevada.usgs.gov/mercury/core.html. For the purposes of this report, the many hundreds of drill-hole lithologic logs from Yucca Flat were culled to a total of 285 holes. The holes from Yucca Flat that were used represented those that contained the greatest amount of detail in the description of each interval, had a large number of downhole intervals described (as opposed to a single long interval of "sand and gravel" or "alluvium"), were representative of downhole lithology of nearby holes, and represented a distribution of holes that were not clustered but were approximately equally distributed over the Yucca Flat area (fig. 2). The thickness of alluvium penetrated by the selected drill holes ranged from less than $100 \mathrm{ft}$ to more than 3,000 ft (fig. 2). The thickness of alluvial fill for the 285 selected holes varies from about $1,000 \mathrm{ft}$ on the alluvial fans near the basin margins to as much as $2,300 \mathrm{ft}$ for holes drilled along the axis of the basin (fig. 2). The 285 holes selected contained 1,430 lithologic intervals, or an average of just over 5 described lithologic intervals per hole.

The original driller's descriptions were simplified to an internally consistent set of 12 general lithologic classes (table 1); lithologic classes were similar to, but fewer in number than, those generated from recent stratigraphic studies of Cenozoic basins to the south of the NTS (Sweetkind and others, 2001; Taylor and Sweetkind, 2005). Lithologic descriptions show that subsurface lithology within the alluvial basin fill is dominated by generally coarse grained sediments; of the 1,430 total described lithologic intervals, 1,328 intervals, or 93 percent, were some combination of sand and gravel.

However, the lithologic descriptions were sufficiently detailed to permit distinguishing cobble and boulder beds from three lithologic classes that contain differing proportions of gravel and sand (table 1). The relative proportions of sand and gravel in these lithologic classes differ from those in standard usage (Folk, 1954), but the proportions used gave a satisfactory distinction between intervals that were dominated by gravel, those where sand and gravel were subequal, and those where

Table 1. Generalized lithologic classes based on drill-hole descriptions.

[mm, millimeter; $\mathrm{cm}$, centimeter]

\begin{tabular}{|c|c|c|}
\hline Lithology class & $\begin{array}{l}\text { Drill-hole } \\
\text { intervals }\end{array}$ & Rationale for classification \\
\hline Gravel & 63 & $\begin{array}{l}\text { Used for cobble beds, boulder beds, and where gravel was reported as having no fine-grained } \\
\text { matrix. }\end{array}$ \\
\hline Sandy gravel & 229 & $\begin{array}{l}\text { Used for sand and gravel mixtures where gravel, clasts, or cobbles were } 70 \text { percent or more of } \\
\text { the total. }\end{array}$ \\
\hline Gravelly sand & 341 & $\begin{array}{l}\text { Used for sand and gravel mixtures where gravel, clasts, or cobbles were subequal in abundance } \\
\text { to the sand component; used where sand was } 30 \text { to } 70 \text { percent of the total. }\end{array}$ \\
\hline $\begin{array}{l}\text { Sand and minor } \\
\quad \text { gravel }\end{array}$ & 360 & $\begin{array}{l}\text { Used for sand and gravel mixtures where the sand component was much more abundant than } \\
\text { gravel, clasts, or cobbles; typically sand was } 70 \text { to } 80 \text { percent of the total, often greater than } \\
90 \text { percent of the total. }\end{array}$ \\
\hline $\begin{array}{l}\text { Sand, clay, and } \\
\text { gravel }\end{array}$ & 42 & $\begin{array}{l}\text { Used for sand and gravel mixtures where silt or clay was identified as an additional important } \\
\text { component. Typically these intervals are dominated by the sand-silt component with rela- } \\
\text { tively minor gravels. }\end{array}$ \\
\hline Coarse sand & 263 & $\begin{array}{l}\text { Used for sand sizes greater than } 0.5 \mathrm{~mm} \text {, typically greater than } 1 \mathrm{~mm} \text {, often with scattered peb- } \\
\text { bles up to } 1 \mathrm{~cm} \text {. }\end{array}$ \\
\hline Fine sand & 44 & Used for sand sizes less than $0.5 \mathrm{~mm}$, rare pebbles. \\
\hline Clay and sand & 12 & $\begin{array}{l}\text { Used for intervals where sands are interbedded with clay layers. Typically explicitly interpreted } \\
\text { in the description as alluvial material interbedded with playa deposits. }\end{array}$ \\
\hline Clay & 2 & $\begin{array}{l}\text { Used for intervals described as almost completely clay. Typically explicitly interpreted in the } \\
\text { description as playa deposit. }\end{array}$ \\
\hline Clay and limestone & 4 & $\begin{array}{l}\text { Used for intervals where clays are interbedded with thin-bedded limestone. Typically explicitly } \\
\text { interpreted in the description as playa deposits. }\end{array}$ \\
\hline Basalt & 3 & Used for intervals where basalt was specifically identified. \\
\hline Nonwelded tuff & 9 & Used for intervals where nonwelded tuff was specifically identified. \\
\hline No data & 39 & Intervals with no useful lithologic information, such as "alluvium." \\
\hline
\end{tabular}


sand was more abundant than gravel (table 1). Of lesser total abundance, but important locally, are intervals of nearly uniform sand, in places accompanied by a very small amount of gravel or individual pebbles. Lithologic descriptions of the sand often were sufficiently detailed to distinguish coarse and "fine sand" (table 1). Intervals described as containing silt were assigned to the lithologic class "fine sand" owing to the limited number of reported instances of silt and to the general difficulty of identifying truly silt-sized particles without rigorous grain-size analysis.

The uppermost described lithologic intervals from the drill holes were compared with the surficial geologic units in Yucca Flat (Slate and others, 2000) using a Geographic Information System (GIS) in hopes of being able to correlate mapped surficial units with subsurface lithologic descriptions. No definitive correlation between mapped units and drill-hole lithologic descriptions was apparent, in large part because surficial units defined by Slate and others (2000) are mapped on the basis of deposit age and degree of induration rather than strictly by lithologic type or grain size.

The level of subsurface detail present in the drill-hole data and the interpreted lithologic classes are portrayed in four cross sections that incorporate drill-hole data along three generally west-east sections (fig. 3) and one generally northsouth section (fig. 4). The drill-hole data on the cross sections are portrayed using general lithologic classes that were derived from the original descriptions (table 1). Drill-hole data within $3,281 \mathrm{ft}$ on either side of the section line are projected onto the line of section, such that each cross section integrates drillhole data within a 6,563-ft-wide swath. Portrayal of numerous drill holes on a single section is a relatively common way to look for overall patterns in subsurface lithologic data (Thorleifson and Pyne, 2004).

Cross section A-A' (fig. 3) at the far north end of Yucca Flat portrays a general progression from coarse, gravelly alluvium high on the alluvial fan on the west side of the basin to finer grained sediments at the basin axis. The coarse-grained alluvium is typically sandy gravel with pebble to cobble-sized clasts. Many of the holes drilled on the fan are between 750 and 1,000 ft deep, yet the alluvial section is described in only one or two intervals. The progressive fining toward the basin center is represented by an increase in the proportion of sand and clay and represents the effects of progressive mechanical abrasion, diminishing depositional energy, and perhaps a greater contribution of fine-grained detritus weathering from volcanic rocks present to the north and east of Yucca Flat (fig. 2). The far eastern end of the cross section portrays an increased quantity of gravel as the fan on the east side of the basin is approached.

Cross section B-B' (fig. 3) portrays lithologic data from drill holes along a southwest-northeast line near the center of the Yucca Flat basin. The drill holes on the east end of the section are shallow and dominated by gravelly sand from a very large alluvial fan that dominates this portion of the east side of the basin (fig. 2). The lithology reported in holes drilled on this fan varies from hole to hole and may represent lithologic variability within the fan, such as individual channels. Drill holes near the center of the section are at the toe of the fan and are dominated by coarse sand or sand with minor gravel, again showing a progressive fining trend toward the basin axis. Drill holes on the west side of the cross section are dominated by relatively coarse grained sediment; these sediments probably have their source in alluvial fans on the west side of the basin but may also show the influence of a large alluvial channel that originates in the northwestern part of Yucca Flat.

Cross section $\mathrm{C}-\mathrm{C}^{\prime}$ (fig. 3) portrays lithologic data from drill holes along a west-east line in the southern part of the Yucca Flat basin, north of the fine-grained sediments of the playa. The center part of section $\mathrm{C}-\mathrm{C}^{\prime}$ is characterized by drill holes that have a consistent lithology dominated by coarse and fine alluvial sand and sand with minor associated gravels. These fine, relatively uniform sands in the south-central portion of the valley must be the result of continued diminishing depositional energy within the alluvial system and also the result of particularly stable conditions of deposition during Late Cenozoic time. On the west side of the section is a drill hole that contains one of the rare basalt flows that lie within the young alluvial fill.

Cross section D-D' (fig. 4) portrays lithologic data from drill holes along a generally north-south profile along the axis of the basin. The northern half of the profile includes drill holes that lie to the west of the Yucca fault; the southern half of the profile includes drill holes that lie to the east of the Yucca fault (fig. 4). Many of the holes possess only one or two described lithologic intervals; yet, when the data from multiple drill holes are taken as a whole, broad lithologic trends may be confidently established. The section displays a broad southward fining from gravel-dominated drill holes in the northern one-third of the section to generally more sand-dominated intervals in the central and southern parts of the section. The north-to-south variation in lithology is complicated by the section's crossing numerous individual alluvial fans and channels. The lithologically homogeneous area of sand portrayed in the center of section $\mathrm{C}-\mathrm{C}^{\prime}$ is evident on this section as well, where a number of holes are dominated by coarse and fine sand and sand with minor gravel. The far southern end of the section includes intervals of thinly bedded, fine-grained clay and limestone that represent the interfingering of the alluvial basin fill with the northernmost extent of playa deposits at the southern end of the basin.

Figure 5 portrays three views of the interpreted lithologic data from the selected drill holes located in 3D space. In these views, the location and drilled depth of drill holes are represented as vertical cylinders; the cylinder diameter and color are varied for separate lithologic classes. In these figures, only the upper portions of the holes are shown in order to emphasize the young alluvium; deeper portions of holes that intercepted Cenozoic volcanic rocks and Paleozoic rocks are not shown. Drill holes are hung at their surface elevations; land surface is transparent so that the drill holes appear to hang in space. The shortened perspective of the east and south views makes holes collared at higher elevations on the west and north side of the 


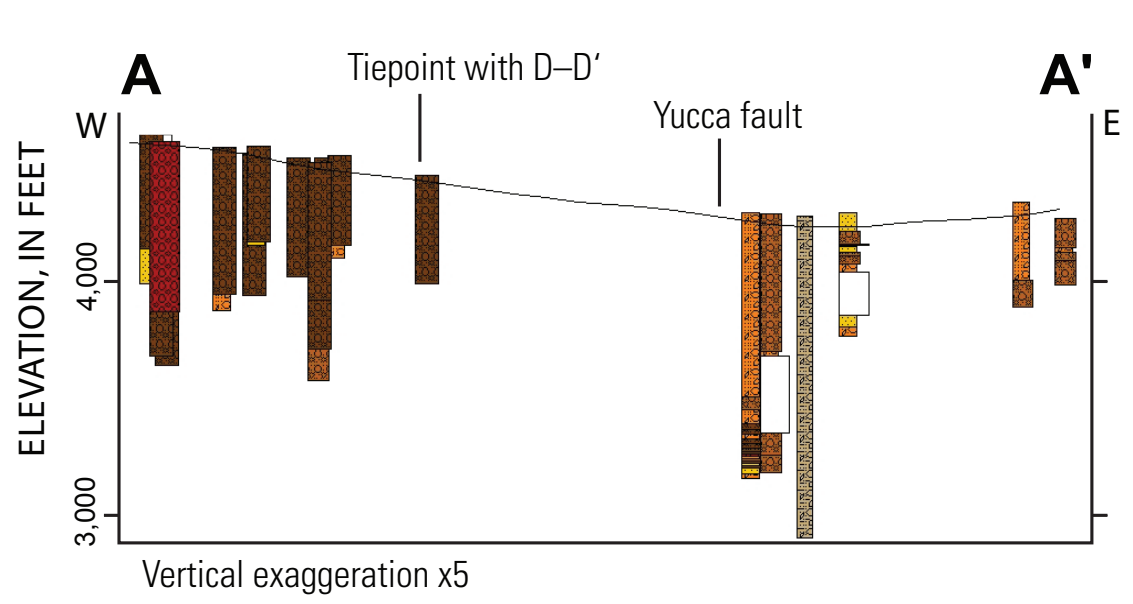

\begin{tabular}{|c|c|}
\hline \multicolumn{2}{|c|}{ EXPLANATION } \\
\hline & Gravel \\
\hline & Sandy gravel \\
\hline & Gravelly sand \\
\hline & Sand and minor gravel \\
\hline & Sand, clay, and gravel \\
\hline & Coarse sand \\
\hline & Fine sand \\
\hline & Clay and sand \\
\hline & Clay \\
\hline & Clay and limestone \\
\hline & Basalt \\
\hline & Nonwelded tuff \\
\hline & No data \\
\hline
\end{tabular}
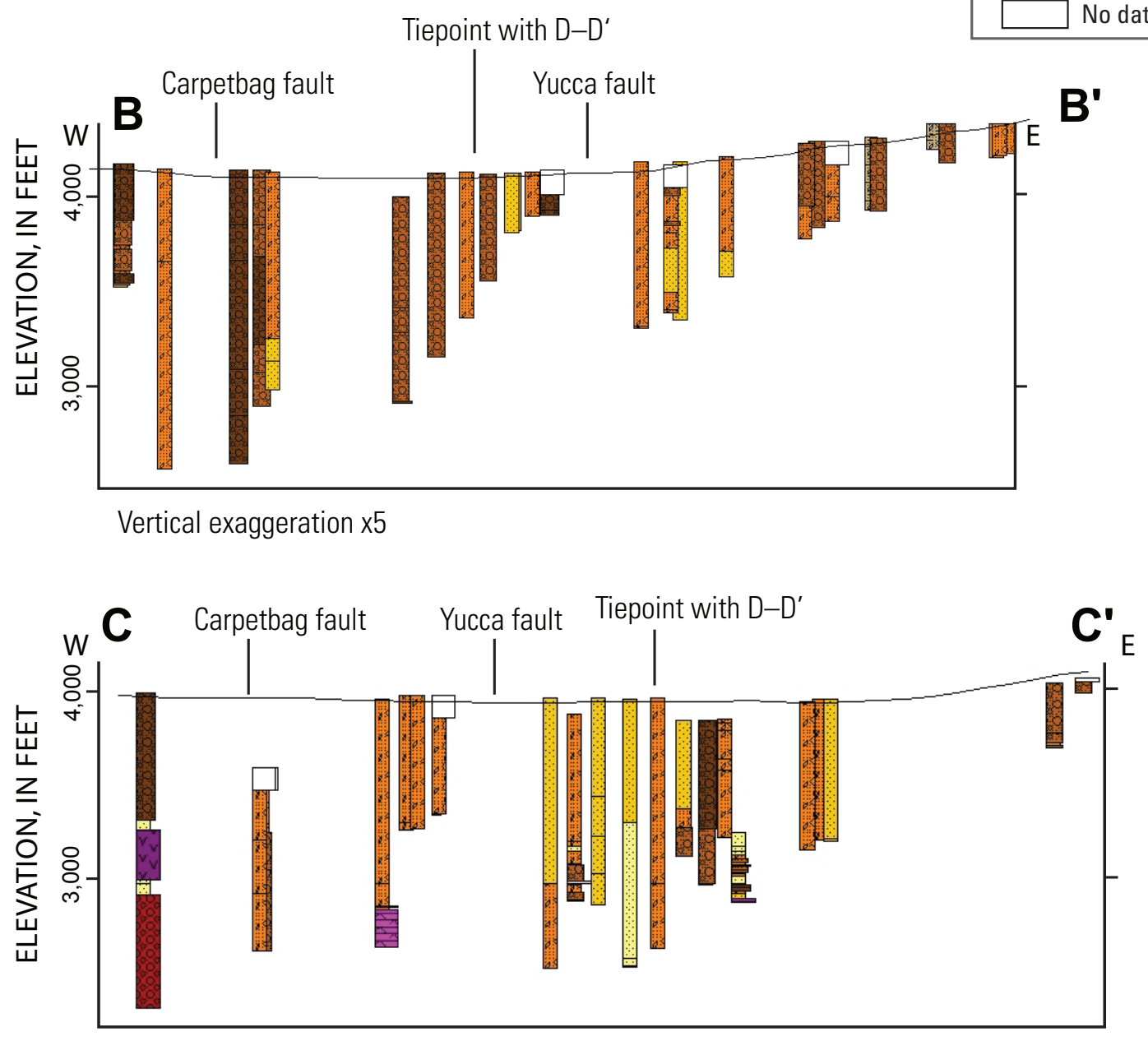

Vertical exaggeration $\times 5$

Location of cross sections shown in figure 2.

Figure 3. West-east cross sections showing interpreted drill-hole lithologic data. 


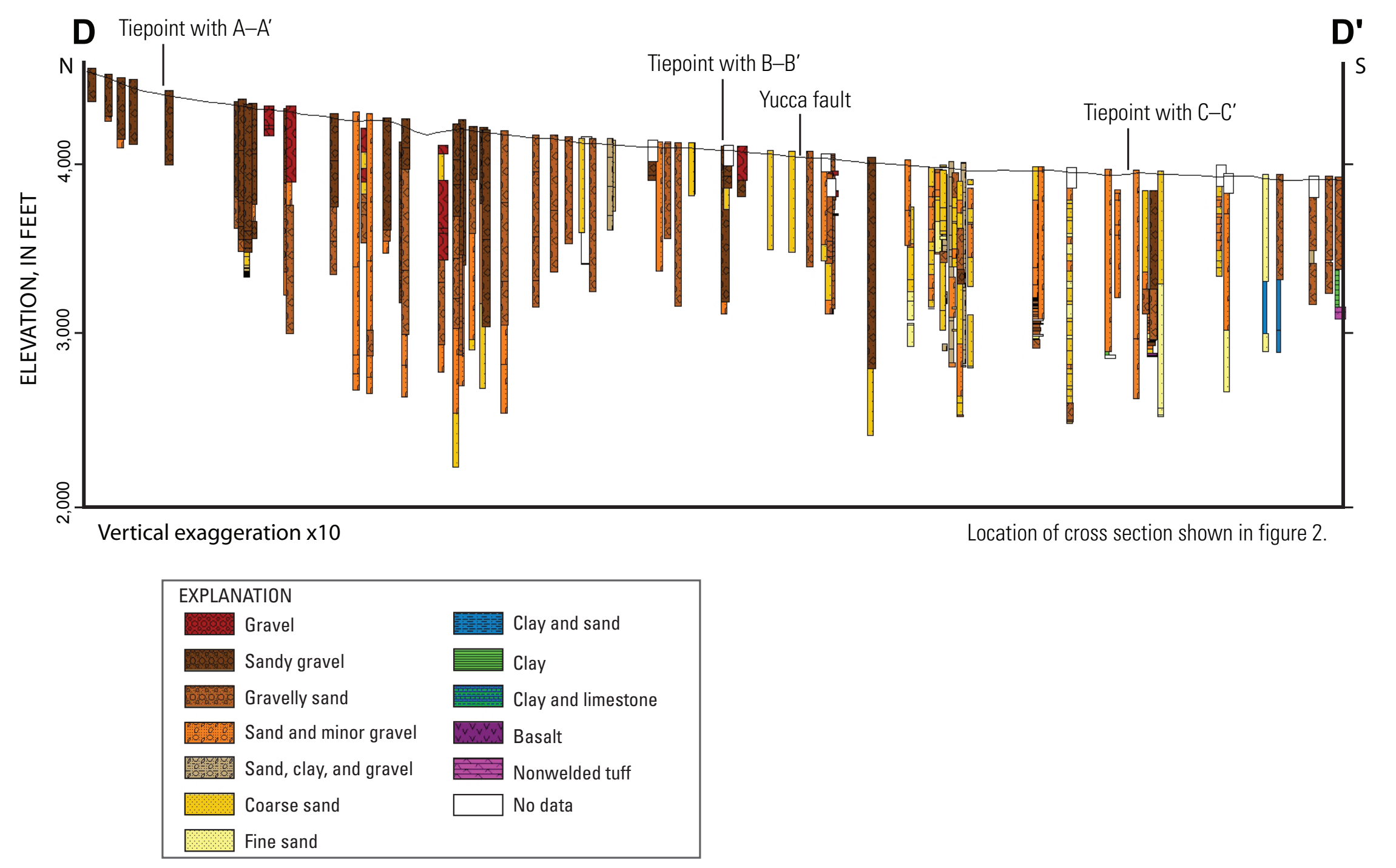

Figure 4. North-south cross section (location, see fig. 2) showing interpreted drill-hole lithologic data. 
basin appear anomalously high relative to the majority of drill holes. These views emphasize the gravel-dominated sections at the northwestern end of the basin and the broad, southwardfining trend to generally more sand-dominated intervals in the central and southern parts of the basin. Intervals dominated by clay, clay and sand, or clay and limestone are present only in the southernmost drill holes in the study region (fig. 5).

\section{D Lithologic Modeling}

Interpreted drill-hole lithologic data were numerically interpolated between drill holes by using a cell-based interpolation called horizontal lithoblending within the RockWorks 2004 software package (Rockware $@$, 2004). Grid nodes are sequentially assigned a value that corresponds to the interpreted lithologic classes based on the proximity to each drill hole. The interpolation routine looks outward horizontally from each drill hole in search circles of ever-increasing diameter. The algorithm assigns the lithology values in each vertical interval of the drill hole to cells immediately surrounding each drill hole. Then the interpolation moves out by a cell and assigns the next "circle" of cells a lithology value for each vertical interval of the drill-hole data. The interpolation continues in this manner until the program finds a cell that is already assigned a lithology (presumably interpolating toward it from an adjacent drill hole), in which case it skips the node assignment step. Near the base of the model, all cell values are controlled by the few deep drill holes; this modeling artifact is removed from the final models by intersecting the solid volume with an arbitrary gridded surface. Cell dimensions for the 3D interpolation were 3,281 ft in the horizontal dimensions and $33 \mathrm{ft}$ in the vertical dimension. We trimmed the resulting model at the top by a grid representing land-surface elevations and at the base by a grid that represents the smoothed base of alluvium present in the selected drill holes. Because there was no information regarding stratal dip in the alluvial section, strata were assumed to be horizontal in this 3D interpolation. The assumption of horizontality is likely more valid for the younger, upper parts of the basin fill than for the deeper parts of the alluvial section.

The strength of this method is that the interpolated data in the resulting 3D grid have the appearance of stratigraphic units, with aspect ratios that emphasize the horizontal dimension over the vertical. Also, the method preserves the local variability of the lithology in each drill hole with no smoothing or averaging. Thus, where data are abundant, local lithologic variability is incorporated. One limitation of this numerical interpolation is the sensitivity to the distribution of the data, where values from an isolated drill hole tend to extrapolate outward to fill an inordinate amount of the model area. The effect is particularly noticeable where a small number of deep drill holes are interspersed with shallower holes; data from the deepest drill holes tend to overextrapolate over the entire model area. We mitigated this effect by trimming the base of the model, using a grid that represents the smoothed base of alluvium present in the selected drill holes. Faults were not explicitly included in the creation of these solid models owing to the limitations of the software package used. However, the interpolation methods used here produce lithologic variations that approximate fault truncations of lithologic units where data density is high.

Six vertical cross sections (fig. 6) cut through the 3D model display the results of the numerical interpolation as a fence diagram that highlights lithologic variations within the basin fill. In the fence diagram, the cross sections are colored according to the interpreted geologic units (fig. 6); land surface is transparent so that the sections appear to hang in space. The upper surfaces of the six sections are clipped at the topographic surface by using a digital elevation model; the base of the model is clipped using a generalized surface that encloses the drilled intervals of alluvial fill for the drill holes used in this study.

The alluvial section on the margins of the basin is represented by relatively thin sections that are dominated by sandy gravel, especially on the west and north, and gravelly sand on the east side of the basin. Deposition of these coarser grained rocks is largely on a series of coalescing alluvial fans that form poorly sorted to moderately sorted deposits in which particle size may range from clay to boulders. Based on surficial mapping (Slate and others, 2000), the lithologic units within these fan complexes tend to be discontinuous and interfingering. The limited number of described lithologic intervals in drill holes that penetrate these fans reveals only hints of the actual lithologic variability. The alluvial fans tend to have a gradational decrease in grain size from proximal to distal fan where they interfinger with sandier units toward the basin axis. The section at $840,000 \mathrm{ft}$ (fig. 6) displays this trend, with sandy gravels on the east and west sides of the basin grading into gravelly sand along the basin axis. There is no clear overall change in grain-size distribution with depth, although there is typically a change in clast lithology. Drill-hole lithologic logs typically report a predominance of Paleozoic rock clasts in the upper parts of the alluvial sections, whereas volcanic rock clasts predominate lower in the alluvial section. Changes in clast lithology are probably a reflection of changes in the available source-rock types as they are exposed to erosion in the surrounding uplands over time.

Several large, active alluvial channels are present around the margin of the basin, the most prominent of which is a surface channel as much as a mile wide that drains the highlands of Rainier Mesa in NTS area 12 in the northwest corner of the Yucca Flat basin (figs. 1, 2). A similar pattern of graveldominated sediment occurs in the subsurface in the northwestern part of the model (fig. 6). A well-defined gravel interval extends southeast and then south and brings gravel and sandy gravel into the axis of the basin as far south as $860,000 \mathrm{ft}$ (fig. 6). Drill-hole data from this subsurface gravel interval indicate coarse, boulder gravels with a mixture of Paleozoic and volcanic rock clasts. Correspondence of the subsurface 


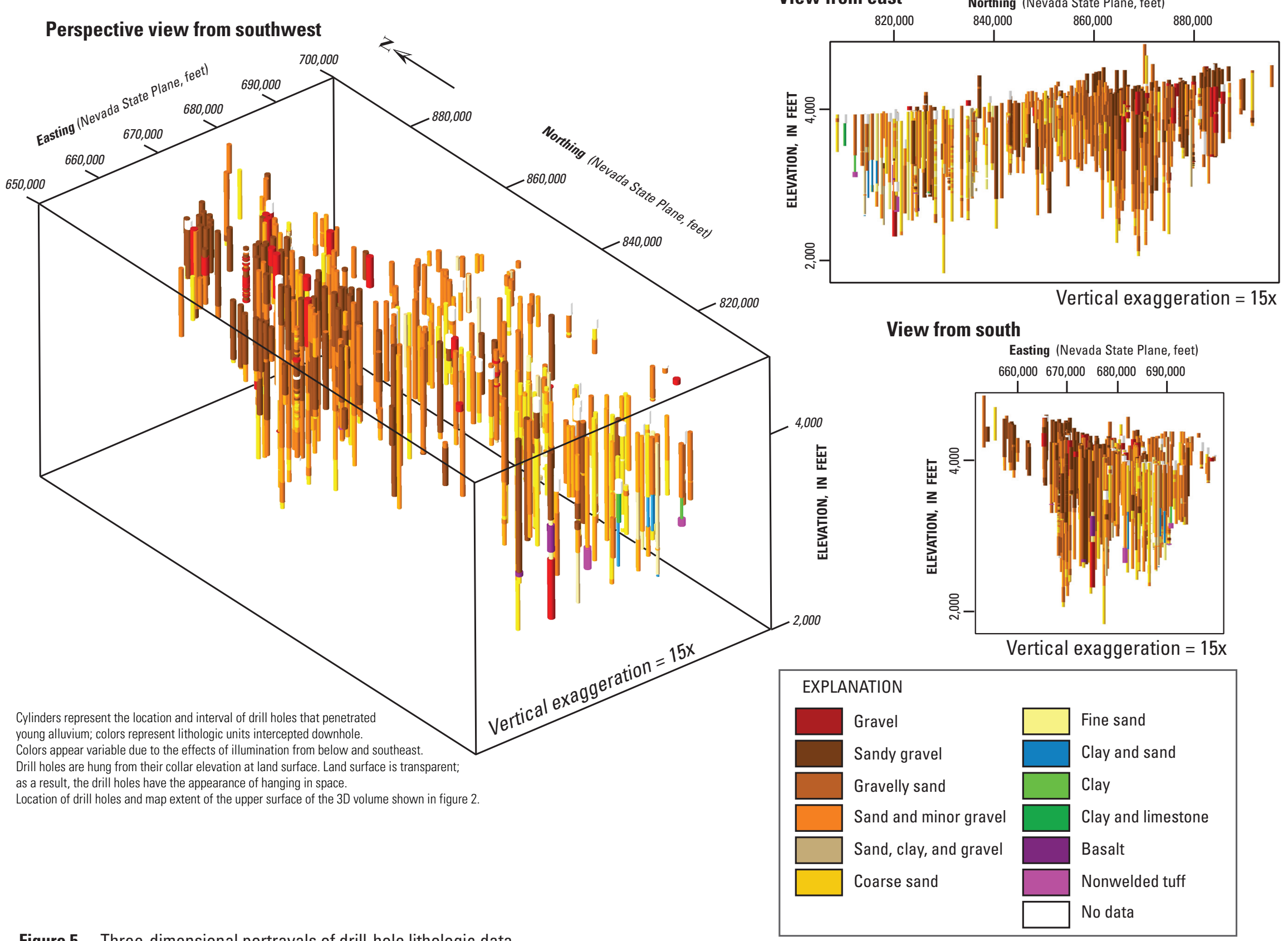

Figure 5. Three-dimensional portrayals of drill-hole lithologic data. 


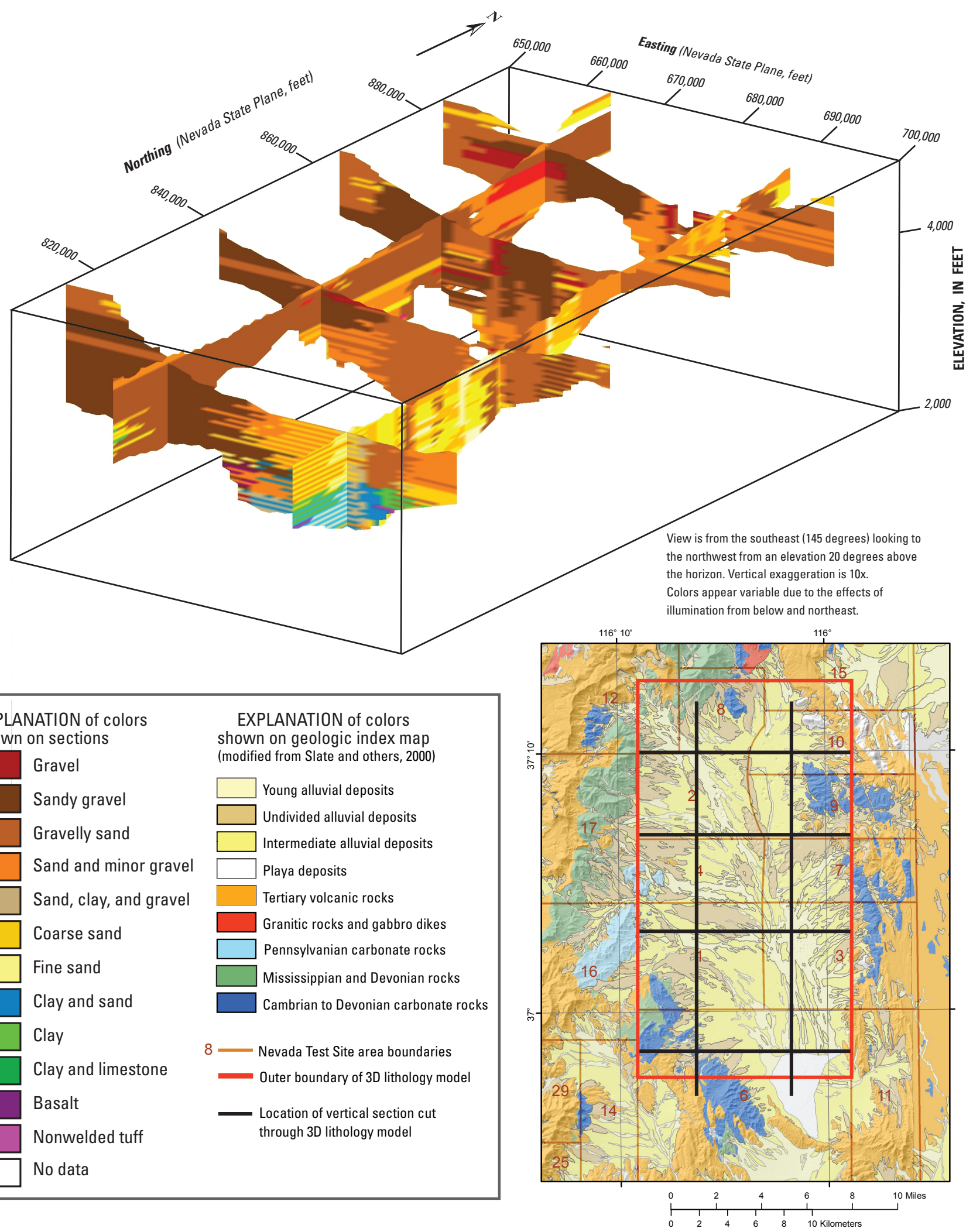

Figure 6. Perspective view of vertical sections cut through 3D lithology model of Yucca Flat. 
gravel interval with the current surface drainage suggests that this drainage system is relatively long-lived.

A uniformly sandy section is present in the southeastern part of the simulated area (fig. 6). Drill-hole data from this area indicate dominantly coarse and fine sand with rare occurrences of pebbles. Limited coring through this sandy interval (A.T. Fernald, written commun., 1983) reveals subhorizontal bedding and suggests a long-lived stable depositional environment to allow the accumulation of this thick interval of sand. Farther to the south, alluvial sediments interfinger with claydominated intervals (fig. 6) that represent the northern extent of sediment associated with the playa at the south end of the basin.

The simulated 3D subsurface distribution of each lithologic class is shown in figure 7 . In these perspective views, only a single lithologic class is portrayed on each view, so the data appear to float in space. The basin fill is dominated by sandy gravel (fig. 7B) and gravelly sand (fig. 7C), especially at the basin margins. The gravel channel in the northwestern part of the basin is especially evident when the gravel class is viewed separately (fig. 7A); deeper gravel accumulations may be the result of older channel systems. Finer grained units including sand and minor gravel (fig. 7D) and sand, clay, and gravel (fig. 7G) tend to occur along the axis of the Yucca Flat basin. The predominance of the uniformly sandy section in the southeastern part of the model is well displayed by the interpolated lithologic data (fig. 7E). Clay-dominated sections occur exclusively at the southern end of the model and represent the interfingering of playa sediments with the alluvial section. Rare basalts occur within the alluvial section (fig. 7H); nonwelded tuffs include airfall units near the base of the alluvial section.

Multiple vertical cross sections (fig. 8) cut through the 3D model display the overall lithologic variations within the basin fill. In the fence diagram, the cross sections are colored according to the interpreted geologic units (fig. 8); land surface is transparent so that the sections appear to hang in space. The upper surface of the model is clipped at the topographic surface by using a digital elevation model; the base of the model is clipped using a generalized surface that encloses the drilled intervals of alluvial fill for the drill holes used in this study. The model was not truncated at the elevation of pre-Cenozoic bedrock and is allowed to extrapolate into areas known to be underlain by pre-Cenozoic bedrock near the margins of the model (fig. 8). These sections clearly depict the sandy gravels associated with alluvial fan complexes along the western and northern margins of the basin; the subsurface extent of coarse gravels associated with the channel in the northwestern part of the model is also visible.

Deterministic modeling of the limited number of drill holes used produces broad lithologic trends, but it does not capture the lithologic details of highly discontinuous alluvial fan and channel complexes. Additional detail could possibly be arrived at through the use of additional drill holes and a finer model grid. However, many of the drill holes are as much as 1,000 ft deep and may be described in only two or three distinct intervals, so some method of improving the vertical lithologic resolution is needed. Analysis of downhole geophysical logs might be of use in defining additional discrete intervals that could be based on inferred grain size or sorting characteristics. Alternatively, it may be possible to use a stochastic approach where the drill-hole data are used as a guide to the subsurface variability (Weissmann and others, 1999). Such an approach could incorporate geologic process by evaluating the tendency of specific lithologic units to be adjacent to each other in specific geologic environments.

\section{Summary}

The purpose of this study is to develop an understanding of lateral and vertical lithologic variability of Neogene sediments that compose the shallow basin fill of Yucca Flat by using a generalized classification of drill-hole lithologic data. As shown in previous stratigraphic studies of Cenozoic basins to the south of the NTS, including the Amargosa Desert Basin (Sweetkind and others, 2001; Taylor and Sweetkind, 2005) and the Pahrump Valley (Sweetkind and others, 2003), careful classification of lithologic data from drill holes can reveal broad subsurface lithologic trends within the basin. Lithologic variations are related to different depositional environments within the basin such as alluvial fan, channel, basin axis, and playa deposits. In the Yucca Flat basin, subsurface trends in general mimic the distribution of surficial deposits, suggesting that depositional environments within the basin have remained stable during Late Cenozoic time.

\section{Acknowledgments}

This study was prepared in cooperation with the U.S. Department of Energy under Interagency Agreement DE-AI52-01NV13944. The authors thank the following individuals who provided data or information for the report: David Wood (USGS) compiled the drill-hole lithologic descriptions that were interpreted in this report, and Jerry Magner (USGS Core Library, Mercury, Nev.) provided access to unpublished reports that were invaluable in refining our interpretations. 

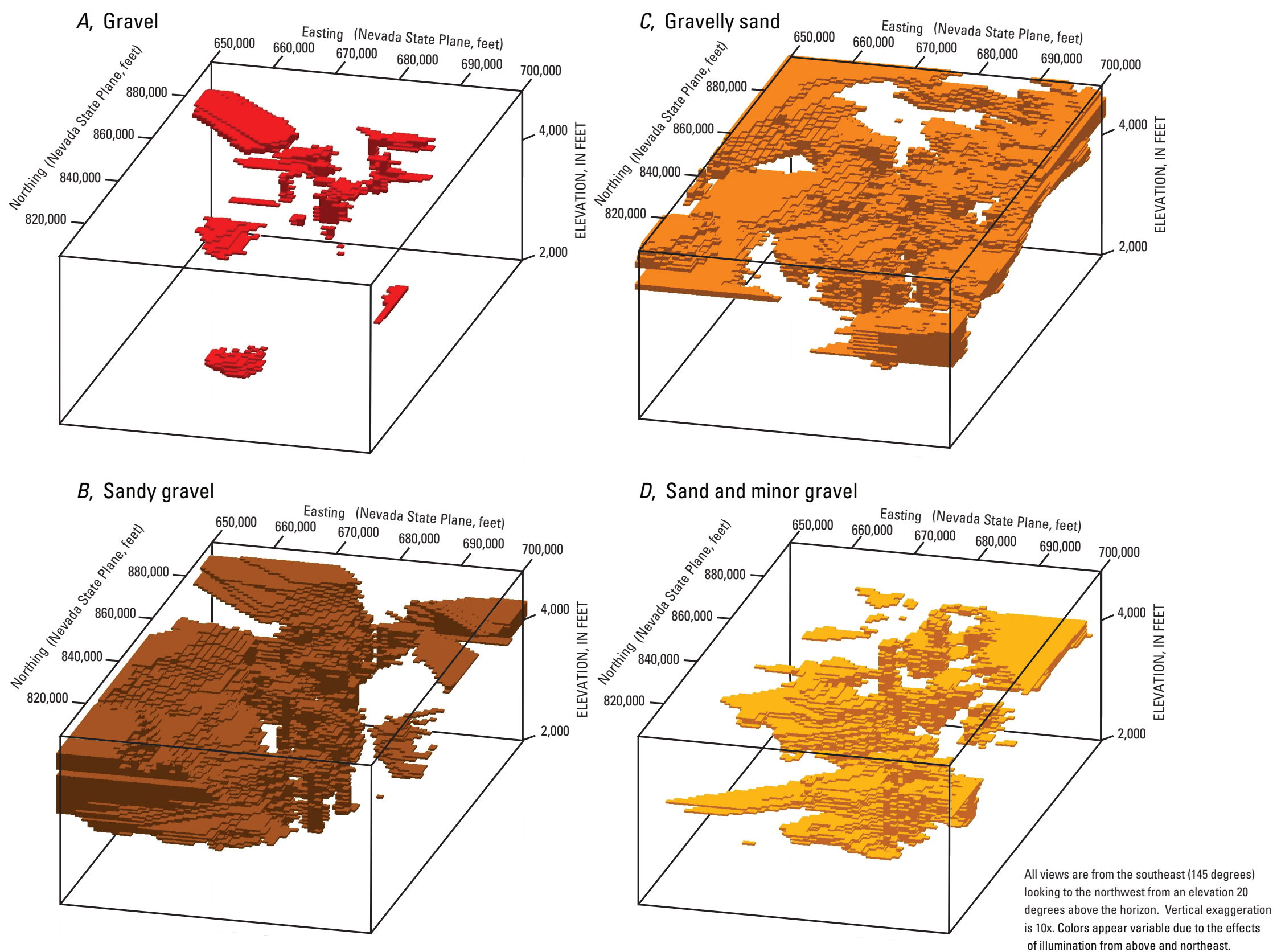

Figure 7. Perspective views of 3D lithologic model showing distribution of lithologic classes. 


\section{$E$, Coarse and fine sand}

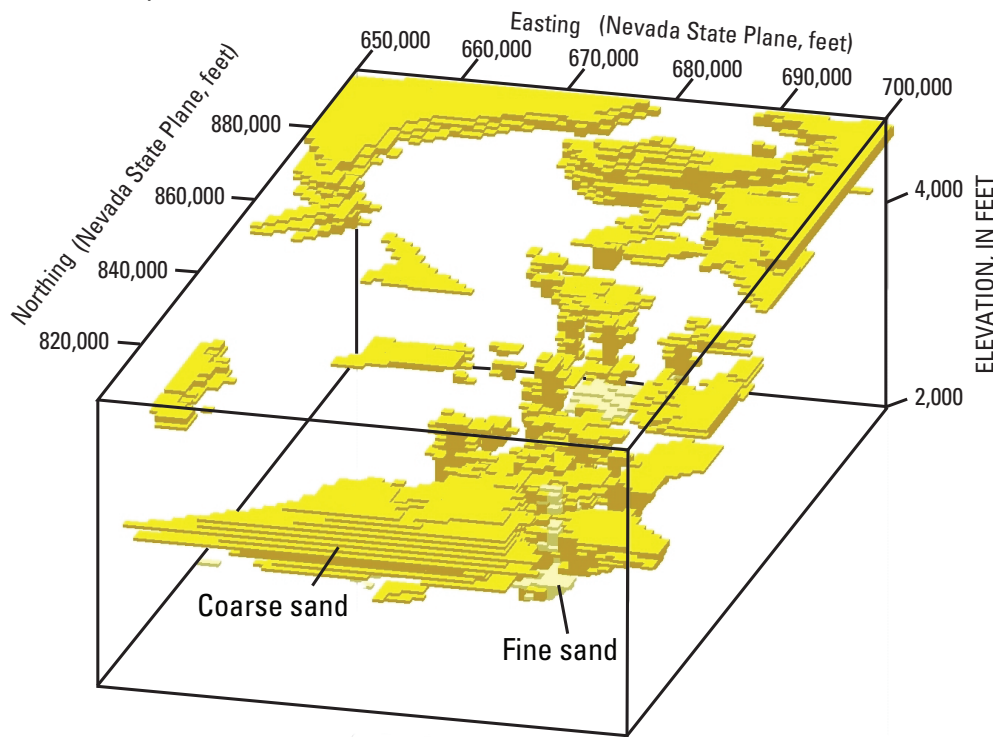

F, Clay; clay and sand; clay and limestone

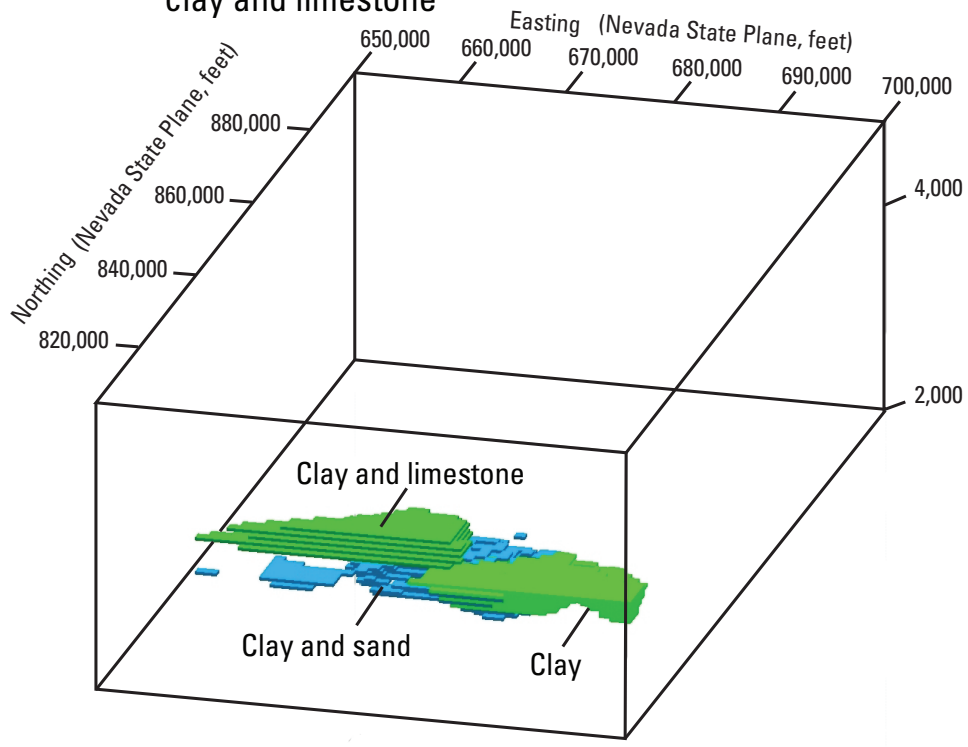

G, Sand, clay, and gravel

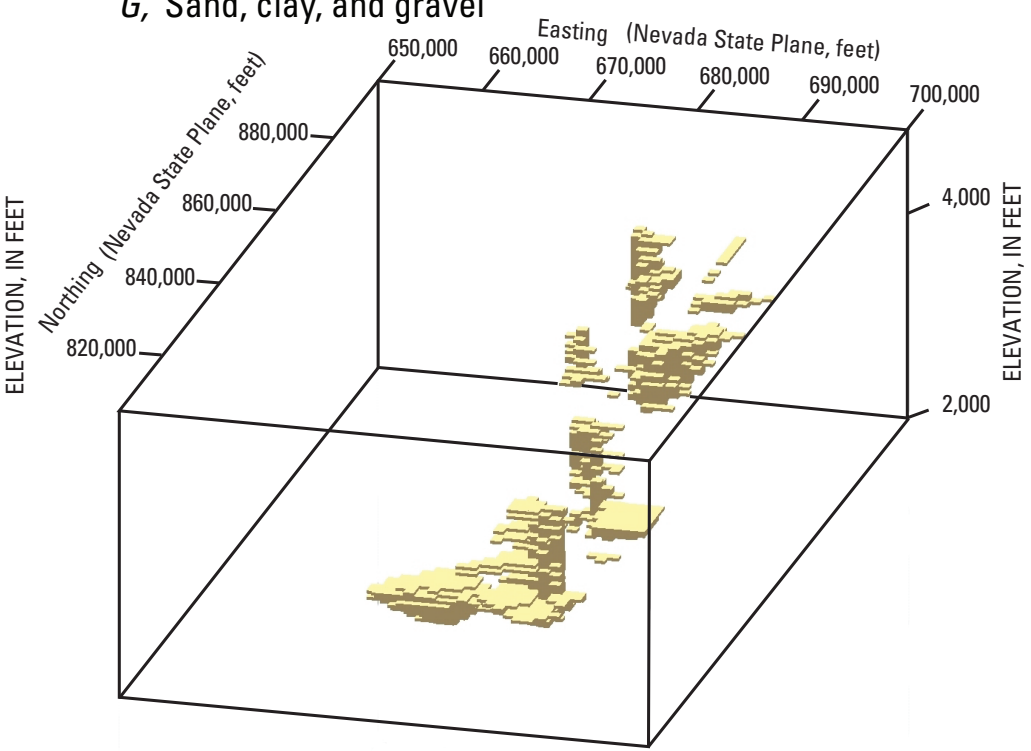

$H$, Basalt; nonwelded tuff

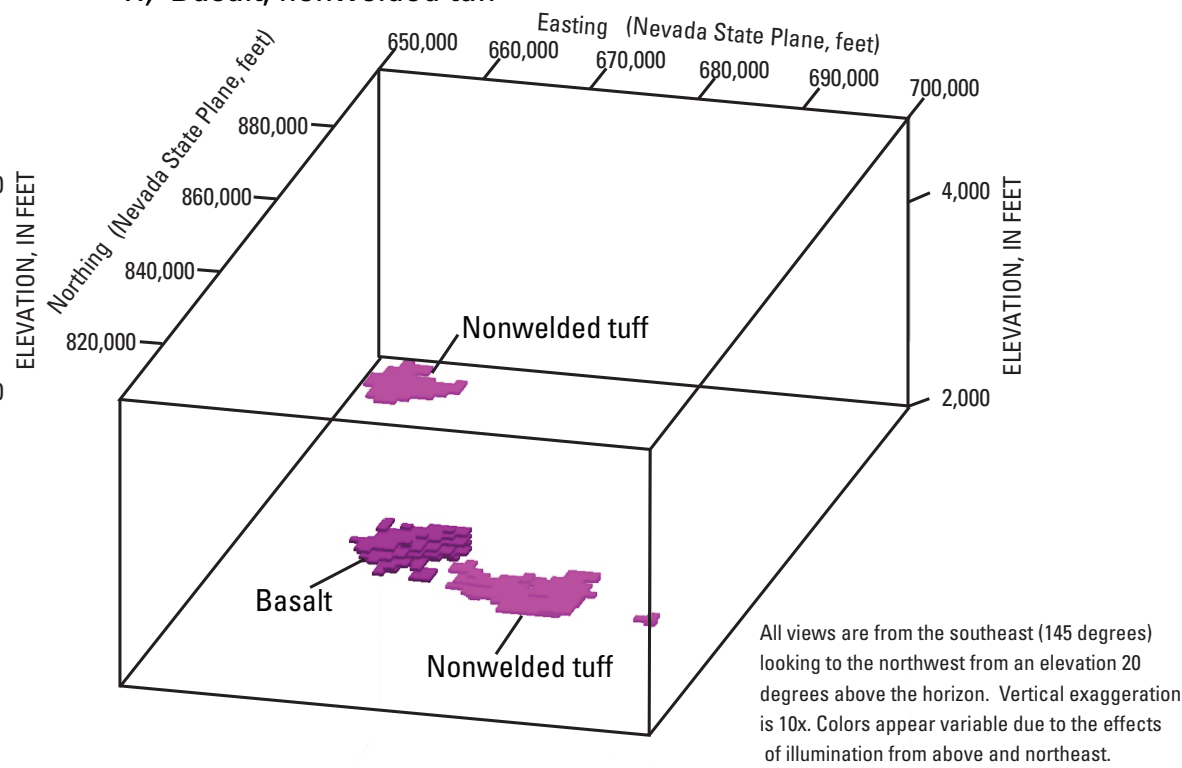

Figure 7. Perspective views of 3D lithologic model showing distribution of lithologic classes-Continued. 


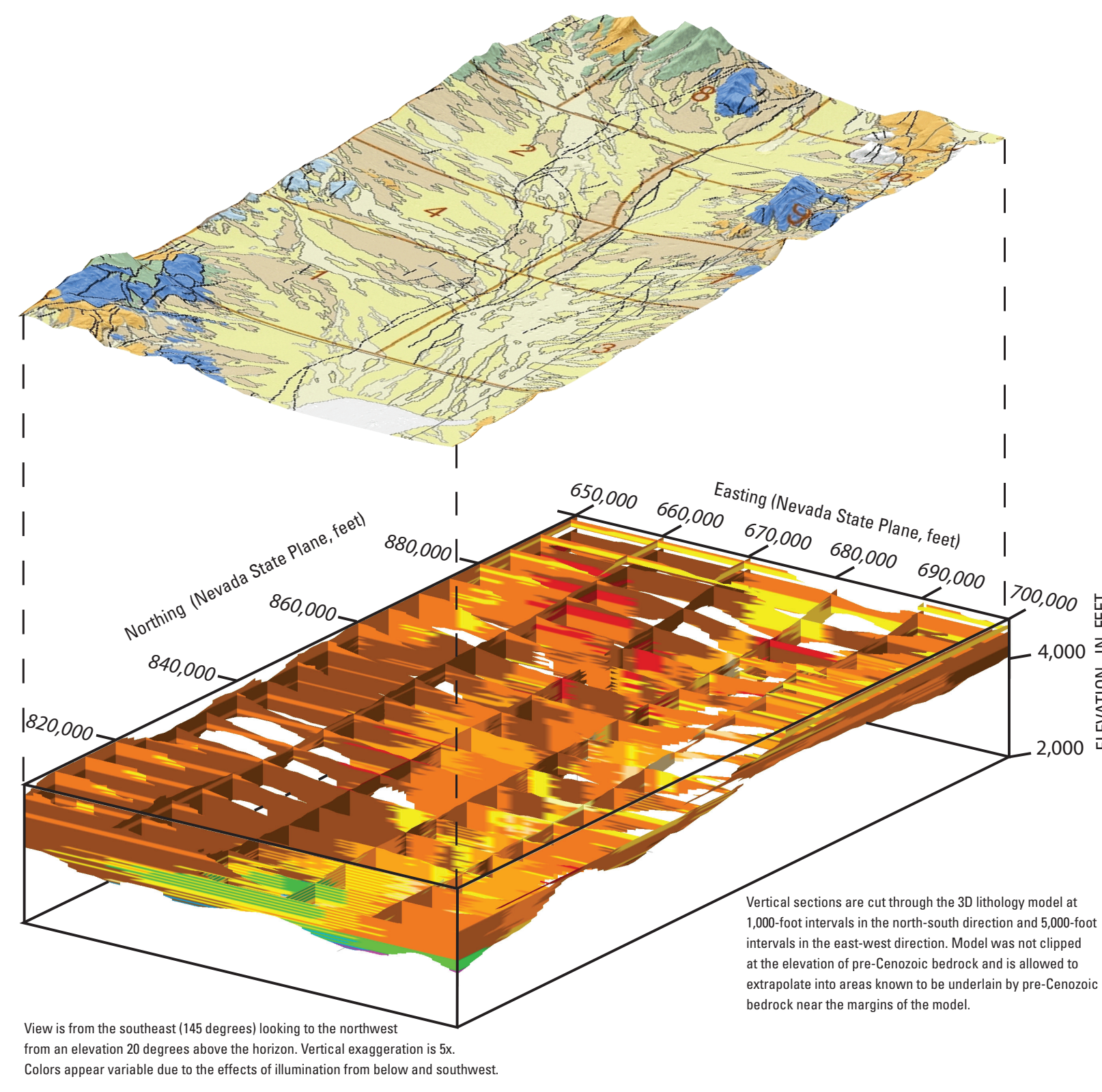

EXPLANATION of colors

shown on geologic map

(modified from Slate and others, 2000)

$\square$ Young alluvial deposits

Undivided alluvial deposits

Intermediate alluvial deposits

Playa deposits

Tertiary volcanic rocks

Granitic rocks and gabbro dikes

Pennsylvanian carbonate rocks

Mississippian and Devonian rocks

Cambrian to Devonian carbonate rocks

— Fault mapped in bedrock

-.-- Fault, concealed

2 Nevada Test Site area boundaries

EXPLANATION of colors shown on sections

\begin{tabular}{|c|}
\hline Gravel \\
\hline Sandy gravel \\
\hline Gravelly sand \\
\hline Sand and minor gravel \\
\hline Sand, clay and gravel \\
\hline Coarse sand \\
\hline Fine sand \\
\hline Clay and sand \\
\hline Clay \\
\hline Clay and limestone \\
\hline Basalt \\
\hline Nonwelded tuff \\
\hline No data \\
\hline
\end{tabular}

Figure 8. Perspective view of multiple vertical sections cut through 3D lithology model of Yucca Flat. 


\section{References Cited}

Byers, F.M., Jr., Carr, W.J., Orkild, P.P., Quinlivan, W.D., and Sargent, K.A., 1976, Volcanic suites and related cauldrons of the Timber Mountain-Oasis Valley caldera complex, southern Nevada: U.S. Geological Survey Professional Paper 919, 70 p.

Carr, W.J., 1984, Regional structural setting of Yucca Mountain, southeastern Nevada, and late Cenozoic rates of tectonic activity in part of the southwestern Great Basin, Nevada and California: U.S. Geological Survey Open-File Report 84-854, 98 p.

Covington, H.R., and Berger, M.A., 1997, Catalogue of lithologic and stratigraphic information from drill holes on the Nevada Test Site and environs: U.S. Geological Survey Open-File Report 97-139, 221 p.

Dockery, Holly, 1984, Rotation of late Cenozoic extensional stresses, Yucca Flat region, Nevada Test Site, Nevada: Houston, Tex., Rice University, Ph.D. thesis, 77 p., 10 plates.

Ferguson, J.F., Felch, R.N., Aiken, C.L.V., Oldow, J.S., and Dockery, Holly, 1988, Models of the Bouguer gravity and geologic structure at Yucca Flat, Nevada: Geophysics, v. 53 , p. $231-244$.

Folk, R.L., 1954, The distinction between grain size and mineral composition in sedimentary rock nomenclature: Journal of Geology, v. 62, p. 344-359.

Hinrichs, E.N., 1968, Geologic structure of the Yucca Flats area, Nevada, in Eckel, E.B., ed., Nevada Test Site: Geological Society of America Memoir 110, p. 239-246.

Phelps, G.A., and McKee, E.H., 1999, High-angle faults in the basement of Yucca Flat, Nevada Test Site, Nevada, based on analysis of a constrained gravity inversion surface: U.S. Geological Survey Open-File Report 99-383, 6 p.

Phelps, G.A., Langenheim, V.E., and Jachens, R.C., 1999, Thickness of Cenozoic deposits of Yucca Flat inferred from gravity data, Nevada Test Site, Nevada: U.S. Geological Survey Open-File Report 99-310, 33 p.

Potter, C.J., Dickerson, R.P., Sweetkind, D.S., Drake II, R.M., Taylor, E.M., Fridrich, C.J., San Juan, C.A., and Day, W.C., 2002, Geologic map of the Yucca Mountain region, Nye County, Nevada: U.S. Geological Survey Geologic Investigations Series I-2755, scale 1;50,000, 1 plate with pamphlet.

Rockware®, 2004, Rockworks 2004 user documentation, http://www.rockware.com/, accessed November 2005.
Sawyer, D.A., Fleck, R.J., Lanphere, M.A., Warren, R.G., Broxton, D.E., and Hudson, M.R., 1994, Episodic caldera volcanism in the Miocene southwestern Nevada volcanic field-Revised stratigraphic framework, ${ }^{40} \mathrm{Ar} /{ }^{39} \mathrm{Ar}$ geochronology, and implications for magmatism and extension: Geological Society of America Bulletin, v. 106, p. 1304-1318.

Slate, J.L., Berry, M.E., Rowley, P.D., Fridrich, C.J., Morgan, K.S., Workman, J.B., Young, O.D., Dixon, G.L., Williams, V.S., McKee, E.H., Ponce, D.A., Hildenbrand, T.G., Swadley, W.C., Lundstrom, S.C., Ekren, E.B., Warren, R.G., Cole, J.C., Fleck, R.J., Lanphere, M.A., Sawyer, D.A., Minor, S.A., Grunwald, D.J., Laczniak, R.J., Menges, C.M., Yount, J.C., and Jayko, A.S., 2000, Digital geologic map of the Nevada Test Site and vicinity, Nye, Lincoln, and Clark Counties, Nevada, and Inyo County, California: U.S. Geological Survey Open-File Report 99-554A, 53 p., scale 1:120,000; at http://pubs.usgs.gov/of/1999/ofr-99-0554/.

Swan, F.H., Wesling, J., Angel, M., Thomas, A., Whitney, J., and Gibson, J., 2001, Evaluation of the location and recency of faulting near prospective surface facilities in Midway Valley, Nye County, Nevada: U.S. Geological Survey OpenFile Report, 2001-055, 1 disc.

Sweetkind, D.S., Fridrich, C.J., and Taylor, E.M., 2001, Facies analysis of Tertiary basin-filling rocks of the Death Valley regional ground-water system and surrounding areas, Nevada and California: U.S. Geological Survey Open-File Report 2001-400, 55 p. Available online at http://pubs.usgs. gov/of/2001/ofr-01-0400/.

Sweetkind, D.S., Taylor, E.M., and Putnam, Heather, 2003, Stratigraphic inferences derived from drill hole data of Tertiary basin-filling rocks of the Pahrump Valley basin, Nevada and California: U.S. Geological Survey Open-File Report 2003-051, 30 p. Available online at http://pubs.usgs. gov/of/2003/ofr-03-051/.

Taylor, E.M., and Sweetkind, D.S., 2005, Using drill hole data and three-dimensional models to map the ground-water system in the Amargosa Desert basin, Nevada and California, in Thorleifson, L.H., and Berg, R.C., Geological models for groundwater flow modeling-Workshop Extended Abstracts: Geological Survey of Canada Open-File Report 5048, p. 93-96.

Thorleifson, L.H., and Pyne, D.M., 2004, Conversion of lithological data in the Manitoba water well database (GWDrill) to a mappable format, in Soller, D.R., ed., Digital Mapping Techniques '03 - Workshop Proceedings: U.S. Geological Survey Open-File Report 2003-471.

U.S. Department of Energy, 2000, United States nuclear tests, July 1945 through September 1992: U.S. Department of Energy, Nevada Operations Office, DOE/NV-209 (rev. 15), 162 p. 
Weissmann, G.S., Carle, S.F., and Fogg, G.E., 1999, Threedimensional hydrofacies modeling based on soil surveys and transition probability geostatistics: Water Resources Research, v. 35, p. 1761-1770.

Workman, J.B., Menges, C.M., Page, W.R., Taylor, E.M., Ekren, E.B., Rowley, P.D., Dixon, G.L., Thompson, R.A., and Wright, L.A., 2002, Geologic map of the Death Valley ground-water model area, Nevada and California: U.S. Geological Survey Miscellaneous Field Studies Map MF2381-A, scale 1:250,000. Accessed September 1, 2004, at http://pubs.usgs.gov/mf/2002/mf-2381/. 
